\title{
Separation of Magnesium Hydroxide and Barium Sulphate from a Barium Sulphate - Magnesium Hydroxide Mixed Sludge by Carbonation: The Effect of Temperature
}

\section{T.T. Rukuni ${ }^{1 *}$, J.P Maree ${ }^{2}$ and C.M Zvinowanda ${ }^{1}$}

${ }^{1}$ Department of Environment, Water \& Earth Sciences, Tshwane University of Technology, Private Bag X680, 0001, Pretoria, South Africa

${ }^{2}$ Incumbent, Rand Water Chair in Water Utilisation, Tshwane University of Technology, Private Bag X680, 0001, Pretoria, South Africa

\begin{abstract}
The solids that result from mine wastewater treatment usually contain elevated levels of contaminants that were originally contained in the wastewater. These must be carefully disposed or treated to avoid shifting of the original pollutants in the waste stream to the final disposal site where they may again become free to contaminate the environment. A more reasonable approach to ultimate solids disposal is to view the sludge as a resource that can be recycled or reused. In South Africa, reverse osmosis is already being used for desalination of mine water and huge sludge volumes are also produced. The Tshwane University of Technology-Magnesium-Barium-Oxide (TUT-MBO) process and its variations is an alternative technology that offers the benefit of lower cost as magnesium hydroxide, barium hydroxide and coal are the main process raw materials. In the first stage $\mathrm{Mg}(\mathrm{OH})_{2}$ is dosed to raise the $\mathrm{pH}$ of the acid mine drainage to 9 for removal of free acid, iron(II) oxidized to iron(III) and all other metals precipitated as metal hydroxides. In the second stage $\mathrm{Ba}(\mathrm{OH})_{2}$ is dosed for magnesium and sulphate removal as $\mathrm{Mg}(\mathrm{OH})_{2}$ and $\mathrm{BaSO}_{4}$ respectively. The resultant, mixed $\mathrm{BaSO}_{4} / \mathrm{Mg}(\mathrm{OH})_{2}$ sludge is treated in a thermal stage to produce $\mathrm{BaS}$ and $\mathrm{MgO}$. The aim of this study was to separate magnesium hydroxide from barium sulphate, produced in the second stage of the TUT-MBO Process. Magnesium hydroxide is separated from barium sulphate through the dissolution of $\mathrm{Mg}(\mathrm{OH})_{2}$ with $\mathrm{CO}_{2}$ to $\mathrm{Mg}\left(\mathrm{HCO}_{3}\right)_{2}$. The results showed that: (a) By adding $\mathrm{CO}_{2}$ to a $\mathrm{BaSO}_{4} / \mathrm{Mg}(\mathrm{OH})_{2}$ sludge, selective dissolution of $\mathrm{Mg}(\mathrm{OH})_{2}$ occurred due to the relatively high solubility of $\mathrm{Mg}\left(\mathrm{HCO}_{3}\right)_{2}$ and the low solubility of $\mathrm{BaSO}_{4}$ and, (b) the solubility of $\mathrm{Mg}\left(\mathrm{HCO}_{3}\right)_{2}$ increased with decreasing temperatures and increasing pressures.
\end{abstract}

Keywords: Acid mine drainage; Precipitation; Dissolution, Reclamation, Carbon dioxide, Sludge disposal

\section{Introduction}

South Africa currently faces both a shortage of water as well as a deterioration of the quality of the available water due to industrial activities such as mining and power generation. The gold mines in Gauteng are expected to decant $345 \mathrm{ML} /$ day of acid mine drainage (AMD) when underground voids have filled up. This water will pollute surface water resources and cause serious environmental impacts [1]. South Africa was one of the first countries to implement commercial scale drinking water reclamation from mine water using reverse osmosis. The cost of reverse osmosis amounts to $\mathrm{R} 10 / \mathrm{m}^{3}$ and produces gypsum, ferric hydroxide rich sludge and brine that have to be disposed at a cost on sludge disposal dumps and brine ponds.

Tshwane University of Technology (TUT) has developed innovative technologies for the neutralization and desalination of acid mine drainage while avoiding gypsum crystallization. These technologies are the Magnesium-Barium-Oxide (TUT-MBO) process and its variations namely; Magnesium-Barium-Bicarbonate (TUT-MBB) process, where magnesium bicarbonate is used instead of magnesium hydroxide, and the Ammonium-Barium (TUT-NB) process [2], where ammonium hydroxide is used instead of magnesium hydroxide to avoid the formation of mixed sludges. Laboratory and pilot studies have demonstrated that magnesium hydroxide or magnesium bicarbonate can be used for removal of metals through precipitation as metal hydroxides. In the processes, magnesium and sulphate removal is achieved by treatment with $\mathrm{Ba}(\mathrm{OH})_{2}$.

The TUT-MBO process and its variations offer the benefit of lower cost as magnesium hydroxide, barium hydroxide and coal are the main process raw materials $[3,4]$. It produces minimum amounts of sludge as process raw materials $\left(\mathrm{Mg}(\mathrm{OH})_{2}\right.$ or $\mathrm{Mg}\left(\mathrm{HCO}_{3}\right)_{2}$ and $\left.\mathrm{Ba}(\mathrm{OH})_{2}\right)$ are recovered from the sludge. Sulphur, a valuable industrial raw material, can also be recovered from the sulphate removed from mine water.
The TUT-MBO process involves two stages. In the first stage, $\mathrm{Mg}(\mathrm{OH})_{2}$ or $\mathrm{Mg}\left(\mathrm{HCO}_{3}\right)_{2}$ is dosed to raise the $\mathrm{pH}$ of the AMD to 9 for removal of free acid, iron(II) as iron(III), and all other metals as metal hydroxides. In the second stage $\mathrm{Ba}(\mathrm{OH})_{2}$ is dosed for magnesium and sulphate removal as $\mathrm{Mg}(\mathrm{OH})_{2}$ and $\mathrm{BaSO}_{4}$, respectively. The resultant, mixed $\mathrm{BaSO}_{4} / \mathrm{Mg}(\mathrm{OH})_{2}$ sludge is treated in a thermal stage to produce a mixture of $\mathrm{BaS}$ and $\mathrm{MgO}$. To avoid this mixture it would be beneficial if $\mathrm{BaSO}_{4}$ and $\mathrm{Mg}(\mathrm{OH})_{2}$ could be separated prior to thermal treatment. This would allow pure $\mathrm{BaSO}_{4}$ to go to the thermal stage where it will be reduced to $\mathrm{BaS}$. The Magnesium bicarbonate solution (TUT-MBB variation) can be used again in the first stage of TUT-MBO process instead of $\mathrm{Mg}(\mathrm{OH})_{2}$. Figure 1 shows the schematic diagram of the TUT-MBB process.

The aim of this study was to explore the separation of magnesium hydroxide from barium sulphate, produced as a mixed sludge in the second stage of the TUT-MBO process, through dissolution of $\mathrm{Mg}(\mathrm{OH})_{2}$ by converting it to $\mathrm{Mg}\left(\mathrm{HCO}_{3}\right)_{2}$ with $\mathrm{CO}_{2}$. By adding $\mathrm{CO}_{2}$ to a $\mathrm{BaSO}_{4} / \mathrm{Mg}(\mathrm{OH})_{2}$, sludge, selective dissolution of $\mathrm{Mg}(\mathrm{OH})_{2}$ occurs according to the following reaction:

$$
\mathrm{CO}_{2(\mathrm{~g})}+\mathrm{Mg}(\mathrm{OH})_{2(\mathrm{~s})}+\mathrm{H}_{2} \mathrm{O}_{(\mathrm{l})} \rightleftharpoons 2 \mathrm{HCO}_{3(\mathrm{aq})}^{-}+\mathrm{Mg}_{(\mathrm{aq})}^{2+}
$$

*Corresponding author: Timothy T Rukuni, Department of Environment, Water \& Earth Sciences, Tshwane University of Technology, Private Bag X680, 0001 Pretoria, South Africa, Tel: +2771 554 3236; E-mail: chivovot@tut.ac.za

Received May 16, 2012; Accepted June 16, 2012; Published June 19, 2012

Citation: Rukuni TT, Maree JP, Zvinowanda CM (2012) Separation of Magnesium Hydroxide and Barium Sulphate from a Barium Sulphate - Magnesium Hydroxide Mixed Sludge by Carbonation: The Effect of Temperature. J Civil Environ Eng 2:116. doi:10.4172/2165-784X.1000116

Copyright: ( 2012 Rukuni TT, et al. This is an open-access article distributed under the terms of the Creative Commons Attribution License, which permits unrestricted use, distribution, and reproduction in any medium, provided the original author and source are credited. 


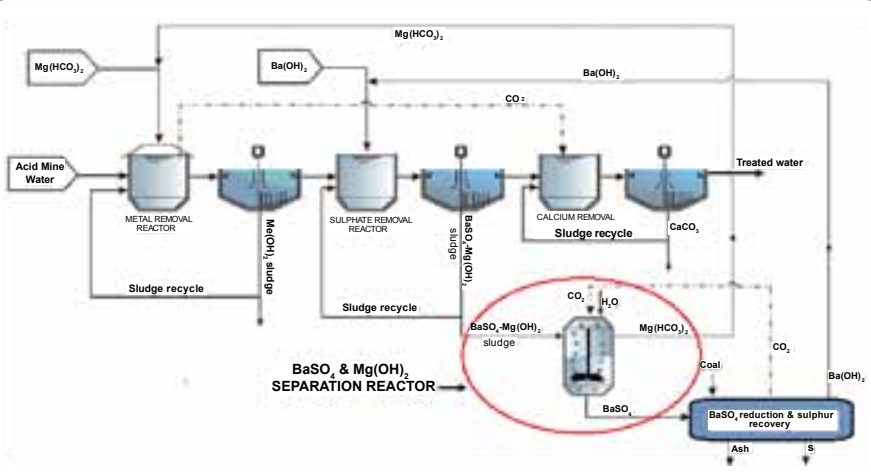

Figure 1: Schematic diagram of the TUT-MBB process for neutralization, metal removal and desalination of AMD.

As the system becomes enriched in $\mathrm{CO}_{2}$, the dissolution rate of $\mathrm{Mg}(\mathrm{OH})_{2}$ could be influenced by its saturation level, $\Omega$.

$$
\Omega=\left[\mathrm{Mg}^{2+}\right]\left[\mathrm{OH}^{-}\right] / \mathrm{K}_{\mathrm{sp}}
$$

Where $\mathrm{K}_{\mathrm{sp}}(\mathrm{T}, \mathrm{S}, \mathrm{p})$ is the solubility product ( $\mathrm{T}$ is temperature, $\mathrm{S}$ is solubility and $\mathrm{p}$ is pressure) [5] with the pressure dependency adjustments by Millero et al. [6].

$$
\mathrm{K}_{\mathrm{sp}}=\left[\mathrm{Mg}^{2+}\right]\left[\mathrm{OH}^{-}\right]
$$

Note: All the square-bracketed species are stoichiometric concentrations (molality or mol $/ \mathrm{kg}$ ) and disregard any complex formation or ion pairs. It is thus necessary to specify not only the $\mathrm{pH}$ scale used in the evaluation of the dissociation constants [7], but also their dependency on ionic strength, temperature, and pressure.

\section{Materials and Methods}

Commercial grade $\mathrm{Mg}(\mathrm{OH})_{2}(60 \mathrm{~g})$ and analytical grade $(14 \mathrm{~g})$ $\mathrm{BaSO}_{4}$ were mixed with deionized water and made up to volume (2 L). Bottled $\mathrm{CO}_{2}$ was used for dissolving $\mathrm{Mg}(\mathrm{OH})_{2}$. Batch studies were carried out using a completely-mixed pressurized reactor (Figure 2). It consisted of a $3 \mathrm{~L}$ reaction vessel equipped with a BirCraft stirrer, temperature sensor, pressure gauge, $\mathrm{pH}$ and conductivity control sensors. This unit was designed to handle pressures up to $10 \mathrm{bar}$ and a maximum temperature of $150^{\circ} \mathrm{C}$. The main body of the reactor was constructed from a Class 12 uPVC pipe with a wall thickness of 3.2 $\mathrm{mm}$ and an internal diameter of $560 \mathrm{~mm}$. The height of the main body was $520 \mathrm{~mm}$ with a uPVC base and top plates that were each $65 \mathrm{~mm}$ thick. The dosage points were $300 \mathrm{~mm}$ above the effluent off-take point that was fitted at the bottom of the reactor. Calcium carbonate and barium sulphate were first fed into the reactor from the top and deionized water was pumped into the reaction vessel with a WatsonMarlow pump with continuous stirring. Carbon dioxide was dissolved in water, under pressure in the reactor, to lower the $\mathrm{pH}$ to around 6 and increase the pressure to desired levels. A pH control unit was used to control $\mathrm{CO}_{2}$ dosage by monitoring the $\mathrm{pH}$. At the end of the reaction the solution was filtered under pressure and the filtrate released from the pressure vessel through a valve.

The effects of the following parameters were investigated: Time $(0$, $10,20,40,60 \mathrm{~min}$ (measured)), Temperature $\left(0,10,25,45^{\circ} \mathrm{C}\right.$ (measured and predicted)), Pressure (predicted), $\mathrm{Mg}(\mathrm{OH})_{2}$ concentration (60 $\mathrm{g} / \mathrm{L}$ (measured and predicted)) and $\mathrm{BaSO}_{4}$ concentration $(0,14 \mathrm{~g} / \mathrm{L}$ (predicted)). The default conditions were $0^{\circ} \mathrm{C}, 60 \mathrm{~g} / \mathrm{L} \mathrm{Mg}(\mathrm{OH})_{2}, 14 \mathrm{~g} / \mathrm{L}$ $\mathrm{BaSO}_{4}$. Filtered samples were collected over $0-60 \mathrm{~min}$ and analyzed for $\mathrm{pH}$, alkalinity, calcium, barium and sulphate. The samples were filtered ( $0.45 \mu \mathrm{m}$ membrane filter) to remove all solid material.
The total dissolved carbonate species were measured by titrating the sample with standard hydrochloric acid to $\mathrm{pH}$ 4.5. The volume of acid was used to calculate the total alkalinity of the sample. From this calculation, the carbonate and hydroxide species concentrations were calculated, and the total carbonate species concentration (as $\mathrm{mg} / \mathrm{L}$ $\left.\mathrm{CaCO}_{3}\right)$.

Magnesium hardness was determined by titration with EDTA $(0.02 \mathrm{M})$ using $\mathrm{P} \& \mathrm{R}$ indicator and $\mathrm{NaOH}$ buffer. Total hardness was determined with EDTA $(0.02 \mathrm{M})$ using EriochromeBlack T indicator and ammonia buffer.

Barium concentrations were determined by titrating the sample with standard $0.02 \mathrm{M}$ EDTA using methylthymol blue indicator, potassium nitrate indicator and $\mathrm{NaOH}$ buffer (for $\mathrm{pH} 12$ ).

The $\mathrm{pH}$, conductivity and pressure in the reactor were measured directly.

\section{Results and Discussion}

Table 1 and Figures 3-7 show the dissolution of $\mathrm{Mg}(\mathrm{OH})_{2}$ (magnesium hydroxide) and $\mathrm{BaSO}_{4}$ (barite) when contacted with $\mathrm{CO}_{2}$ in water under various conditions. The Figures 3-7 contain measured values while Table 1 contains both measured and predicted values. The predictions were done using a Visual MINTEQ model [8,9].

\section{Separation of $\mathrm{Mg}(\mathrm{OH})_{2}$ and $\mathrm{BaSO}_{4}$}

The mixture of $\mathrm{Mg}(\mathrm{OH})_{2}$ and $\mathrm{BaSO}_{4}$ sludge produced by the TUT$\mathrm{MBO}$ process cannot be separated by solubility differences due to the low solubility of both $\mathrm{Mg}(\mathrm{OH})_{2}(3.8 \mathrm{mg} / \mathrm{LMg})$ and $\mathrm{BaSO}_{4}(5.6 \mathrm{mg} / \mathrm{L}$

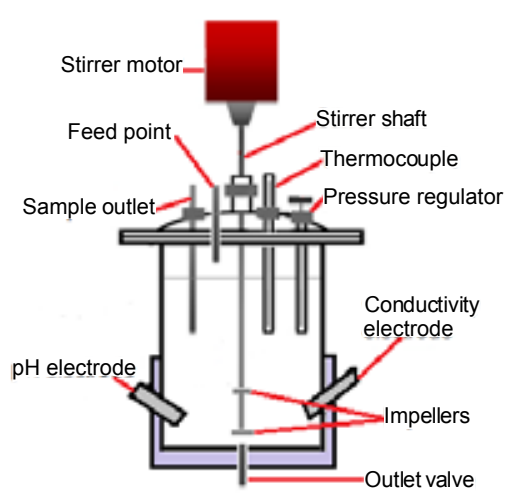

Figure 2: The completely-mixed pressurized reactor

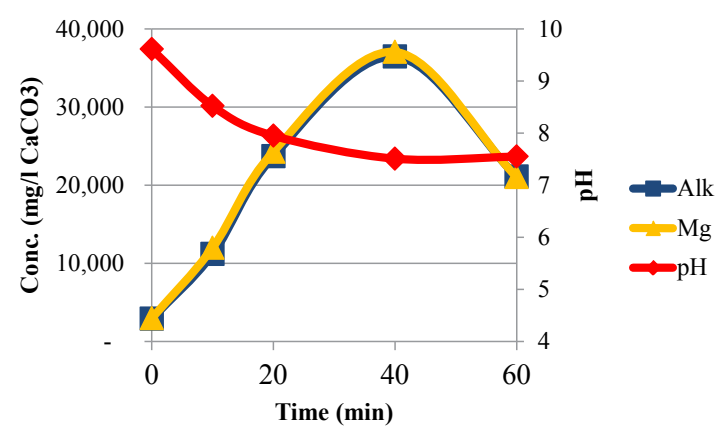

Figure 3: Behaviour of various parameters during contact between $\mathrm{Mg}(\mathrm{OH})_{2}$ and $\mathrm{CO}_{2}\left(\mathrm{Temp}=10^{\circ} \mathrm{C} ; 60 \mathrm{~g} / \mathrm{L} \mathrm{Mg}(\mathrm{OH})_{2}\right)$. 
Citation: Rukuni TT, Maree JP, Zvinowanda CM (2012) Separation of Magnesium Hydroxide and Barium Sulphate from a Barium Sulphate Magnesium Hydroxide Mixed Sludge by Carbonation: The Effect of Temperature. J Civil Environ Eng 2:116. doi:10.4172/2165-784X.1000116

Page 3 of 5

\begin{tabular}{|c|c|c|c|c|c|c|c|c|c|}
\hline \multirow[t]{2}{*}{ Exp No } & \multicolumn{2}{|l|}{ Feedstock } & \multirow{2}{*}{$\begin{array}{l}\text { Sulphate in } \\
\text { treated water } \\
\text { (mg/l) }\end{array}$} & \multicolumn{2}{|l|}{ pH } & \multirow[t]{2}{*}{ Temp } & \multicolumn{2}{|c|}{ Alk (mg/l CaCO3) (aq) } & \multirow{2}{*}{$\begin{array}{l}\text { Ba in solution }(\mathrm{mg} / \mathrm{l}) \\
\text { Predicted }\end{array}$} \\
\hline & $\mathrm{Mg}(\mathrm{OH}) 2(\mathrm{~s})(\mathrm{g} / \mathrm{l})$ & $\begin{array}{l}\text { BaSO4 (s) } \\
(\mathrm{g} / \mathrm{l})\end{array}$ & & Predicted & Determined & & Predicted & Determined & \\
\hline & \multicolumn{8}{|c|}{ DeterminedPredictedBehaviour of various parameters (see Figure 3) } & \\
\hline \multirow[t]{2}{*}{1.2} & 60 & 0 & 1 & & 7.55 & 10 & 60,000 & 21,100 & \\
\hline & \multicolumn{9}{|c|}{ Solubility of $\mathrm{Mg}(\mathrm{OH})_{2}$ and $\mathrm{BaSO}_{4}$ when in contact with $\mathrm{CO}_{2} ; \mathrm{pH}$ and $\mathrm{Mg}$ measured and predicted (Figure 4) } \\
\hline 1.2 & 60 & 0 & 1 & & 7.55 & 10 & 60,000 & 21,100 & \\
\hline \multirow[t]{2}{*}{3.2} & 0 & 20 & 1 & & 6.81 & 10 & - & 50 & \\
\hline & \multicolumn{9}{|c|}{ Effect of $\mathrm{BaSO}_{4} ; \mathrm{pH}, \mathrm{Mg}$ and $\mathrm{Ba}$ measured and predicted (Figure 5) } \\
\hline 1.1 & 60 & 0 & 1 & & 7.44 & 0 & 60,000 & 21,000 & \\
\hline 2.1 & 60 & 14 & 1 & 7.67 & 6.01 & 0 & 60,000 & 21,000 & 6.43 \\
\hline 1.2 & 60 & 0 & 1 & & 7.55 & 10 & 60,000 & 21,000 & \\
\hline \multirow[t]{2}{*}{2.2} & 60 & 14 & 1 & & 7.55 & 10 & 60,000 & 19,796 & \\
\hline & \multicolumn{9}{|c|}{ Effect of temperature on $\mathrm{Mg}(\mathrm{OH})_{2} ; \mathrm{pH}$ and $\mathrm{Mg}$ predicted and measured (see Figure 6) } \\
\hline 1.1 & 60 & 0 & 1 & & 7.44 & 0 & 60,000 & 21,000 & \\
\hline 1.2 & 60 & 0 & 1 & & 7.55 & 10 & 60,000 & 21,000 & \\
\hline 1.3 & 60 & 0 & 1 & & 7.45 & 25 & 60,000 & 17,600 & \\
\hline \multirow[t]{2}{*}{1.4} & 60 & 0 & 1 & & 7.38 & 45 & 60,000 & 12,300 & \\
\hline & \multicolumn{8}{|c|}{ Effect of temperature on $\mathrm{Mg}(\mathrm{OH})_{2}$ and $\mathrm{BaSO}_{4} ; \mathrm{pH}, \mathrm{Mg}$ and $\mathrm{Ba}$ predicted and measured (see Figure 7) } & \\
\hline 2.1 & 60 & 14 & 1 & 7.67 & 6.01 & 0 & 60,000 & 22,700 & 6.43 \\
\hline 2.2 & 60 & 14 & 1 & & 7.55 & 10 & 60,000 & 19,796 & 9.17 \\
\hline 2.3 & 60 & 14 & 1 & & 7.47 & 25 & 60,000 & 20,000 & 14.67 \\
\hline \multirow[t]{2}{*}{2.4} & 60 & 14 & 1 & & 7.48 & 45 & 60,000 & 8,000 & 24.29 \\
\hline & \multicolumn{8}{|c|}{ Effect of sulphate on $\mathrm{Mg}(\mathrm{OH})_{2} ; \mathrm{pH}, \mathrm{Ba}$ and $\mathrm{Mg}(\mathrm{OH})_{2}$ predicted (Figure 8$)$} & \\
\hline 4.1 & 60 & 0 & 0 & 7.67 & & 0 & 60,000 & & 6.43 \\
\hline 4.2 & 60 & 0 & 9.6 & 7.67 & & 0 & 60,000 & & 2.75 \\
\hline 4.3 & 60 & 0 & 48 & 7.67 & & 0 & 60,000 & & 0.66 \\
\hline 4.4 & 60 & 0 & 96 & 7.67 & & 0 & 60,000 & & 0.34 \\
\hline \multirow[t]{2}{*}{4.5} & 60 & 0 & 192 & 7.67 & & 0 & 60,000 & & 0.17 \\
\hline & \multicolumn{9}{|c|}{ Effect of sulphate on $\mathrm{Mg}(\mathrm{OH})_{2} ; \mathrm{pH}, \mathrm{Ba}$ and $\mathrm{Mg}(\mathrm{OH})_{2}$ predicted (Figure 8) } \\
\hline 5.1 & 60 & 14 & 0 & 7.76 & & 25 & 60,000 & & 14.67 \\
\hline 5.2 & 60 & 14 & 9.6 & 7.75 & & 25 & 60,000 & & 9.75 \\
\hline 5.3 & 60 & 14 & 48 & 7.76 & & 25 & 60,000 & & 3.32 \\
\hline 5.4 & 60 & 14 & 96 & 7.76 & & 25 & 60,000 & & 1.72 \\
\hline 5.5 & 60 & 14 & 192 & 7.76 & & 25 & 60 & & 0.87 \\
\hline
\end{tabular}

Table 1: Effect of various parameters on the solubility of $\mathrm{Mg}(\mathrm{OH})_{2}$ and $\mathrm{BaSO}_{4}$ in a $\mathrm{CO}_{2}$-rich solution.

$\mathrm{Ba})$. As $\mathrm{CO}_{2}$ is produced as a waste product in the TUT-MBO process, it was decided to investigate whether $\mathrm{Mg}(\mathrm{OH})_{2}$ could be separated from the almost insoluble $\mathrm{BaSO}_{4}$ by dissolving it as $\mathrm{Mg}\left(\mathrm{HCO}_{3}\right)_{2}$ (Equation1), by contacting the sludge mixture with $\mathrm{CO}_{2}$. Figure 3 shows that $60 \mathrm{~g} / \mathrm{L}$ $\mathrm{Mg}(\mathrm{OH})_{2}$ dissolved partially when contacted with $\mathrm{CO}_{2}$ at 1 atm. As $\mathrm{Mg}\left(\mathrm{HCO}_{3}\right)_{2}$ formed, $\mathrm{Mg}$ and alkalinity (Alk) values increased rapidly to $36458 \mathrm{mg} / \mathrm{L}$ (as $\mathrm{CaCO}_{3}$ ), whereafter it dropped to $21100 \mathrm{mg} / \mathrm{L}$ (as $\mathrm{CaCO}_{3}$ ). The maximum solubility value of $36358 \mathrm{mg} / \mathrm{L}$ can be explained by the high solubility of $\mathrm{Mg}\left(\mathrm{HCO}_{3}\right)_{2}$, the intermediate product when $\mathrm{Mg}(\mathrm{OH})_{2}$ is contacted with $\mathrm{CO}_{2}$. Except for $\mathrm{Mg}\left(\mathrm{HCO}_{3}\right)_{2}$, there are also other $\mathrm{Mg}$ species present in the system, such as artinite, brucite, hydromagnesite, magnesite, magnesium hydroxide, magnesium carbonate, nesquehonite and periclase. The Visual Minteq [8,9] model showed that some of these compounds exceeded their solubilities as indicated by the positive saturation index values. Precipitation of the compounds that were over saturated would explain the observed drop in $\mathrm{Mg}\left(\mathrm{HCO}_{3}\right)_{2}$ concentration in solution from 36358 to $21100 \mathrm{mg} / \mathrm{L}$ $\mathrm{Mg}\left(\mathrm{HCO}_{3}\right)_{2}\left(\right.$ as $\left.\mathrm{CaCO}_{3}\right)$. It also showed the ionic balance between the measured calcium concentration and the total alkalinity of the system.
Over the same period the $\mathrm{pH}$ dropped from 9.6 to 7.6. The dissolution of $\mathrm{Mg}(\mathrm{OH})_{2}$ increased with decreased $\mathrm{pH}$ due to the increased formation of soluble $\mathrm{Mg}\left(\mathrm{HCO}_{3}\right)_{2}$. Therefore, $\mathrm{CO}_{2}$ dosing lowers the $\mathrm{pH}$, and magnesium hydroxide is converted to $\mathrm{Mg}\left(\mathrm{HCO}_{3}\right)_{2}$.

Alkalinity was used to monitor the formation of $\mathrm{Mg}\left(\mathrm{HCO}_{3}\right)_{2}$ and includes the parameters listed in Equation (4). As the system became enriched in $\mathrm{CO}_{2}$, the extent of dissolution decreased as a function of changes in the $\mathrm{Mg}(\mathrm{OH})_{2}$ saturation state to yield both magnesium ions and Alk (Equation 1).

$$
\mathrm{Alk}=2\left[\mathrm{CO}_{3}{ }^{2-}\right]+\left[\mathrm{HCO}_{3}^{-}\right]+\left[\mathrm{OH}^{-}\right]+\left[\mathrm{H}^{+}\right]
$$

Figure 4 shows the contrast between the solubilities of $\mathrm{Mg}(\mathrm{OH})_{2}$ $\left(21100 \mathrm{mg} / \mathrm{L}\right.$ as $\left.\mathrm{CaCO}_{3}\right)$ and $\mathrm{BaSO}_{4}\left(50 \mathrm{mg} / \mathrm{L}\right.$ as $\left.\mathrm{CaCO}_{3}\right)$. The results showed that, as expected, $\mathrm{BaSO}_{4}$ does not dissolve when contacted with $\mathrm{CO}_{2}$ and consequently there were negligible losses of $\mathrm{BaSO}_{4}$ due to dissolution.

The effect of $\mathrm{BaSO}_{4}$ on the rate of formation and solubility of $\mathrm{Mg}\left(\mathrm{HCO}_{3}\right)_{2}$ was studied. Figure 5 showed that $\mathrm{BaSO}_{4}$ had no effect on 


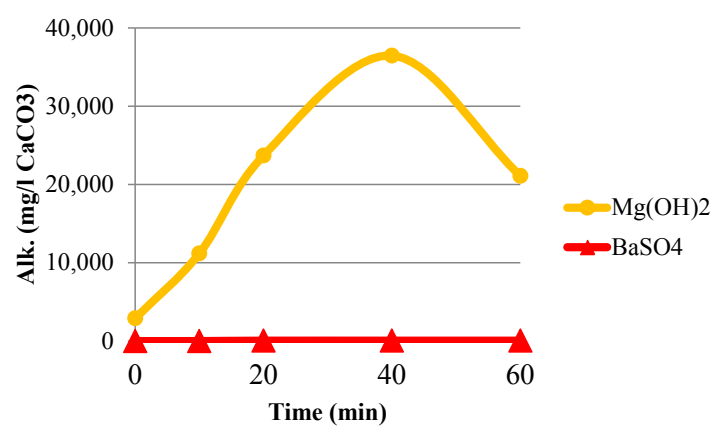

Figure 4: Comparison between dissolution of $\mathrm{Mg}(\mathrm{OH})_{2}$ and $\mathrm{BaSO}_{4}$ in a $\mathrm{CO}_{2}$ rich solution $\left(10^{\circ} \mathrm{C} ; 60 \mathrm{~g} / \mathrm{L} \mathrm{Mg}(\mathrm{OH})_{2} ; 14 \mathrm{~g} / \mathrm{L} \mathrm{BaSO}_{4}\right)$.

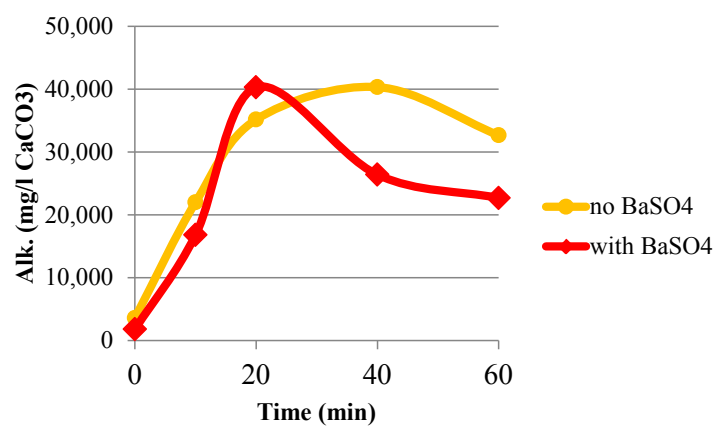

Figure 5: Effect of $\mathrm{BaSO}_{4}$ on the rate of formation and solubility of $\mathrm{Mg}\left(\mathrm{HCO}_{3}\right)_{2}$ $\left(0^{\circ} \mathrm{C}, 60 \mathrm{~g} / \mathrm{L} \mathrm{Mg}(\mathrm{OH})_{2}\right.$, no $\mathrm{BaSO}_{4} ; 60 \mathrm{~g} / \mathrm{L} \mathrm{Mg}(\mathrm{OH})_{2}$ and $\left.14 \mathrm{~g} / \mathrm{L} \mathrm{BaSO}_{4}\right)$.

the solubility of $\mathrm{Mg}\left(\mathrm{HCO}_{3}\right)_{2}$. This was because $\mathrm{BaSO}_{4}$ does not react with $\mathrm{CO}_{2}$. The known low solubility of $\mathrm{BaSO}_{4}$ was also reflected by the low predicted values for $\mathrm{Ba}^{2+}$ in solution, when $\mathrm{BaSO}_{4}$ is contacted with $\mathrm{CO}_{2}$ (Table 1).

\section{Effect of temperature on solubility}

In the previous section it was shown that $\mathrm{Mg}(\mathrm{OH})_{2}$ can be dissolved by the formation of $\mathrm{Mg}\left(\mathrm{HCO}_{3}\right)_{2}$, through $\mathrm{CO}_{2}$ addition without affecting the low solubility of $\mathrm{BaSO}_{4}$. The sludge separation process will be more effective at higher solubility values for $\mathrm{Mg}\left(\mathrm{HCO}_{3}\right)_{2}$. Therefore, it was decided to determine the effect of temperature on the solubilisation of $\mathrm{Mg}(\mathrm{OH})_{2}$ as $\mathrm{Mg}\left(\mathrm{HCO}_{3}\right)_{2}$. According to Henry's law (Equation 5), it was expected that the solubility should increase with decreasing temperatures. Figures 6 and 7 confirmed the validity of Henry's law. In the case of Figure 6, only $\mathrm{Mg}(\mathrm{OH})_{2}$ was present in the slurry used, whilst in Figure $7, \mathrm{BaSO}_{4}$ was also present. As in the previous case, it was found that $\mathrm{BaSO}_{4}$ had no effect on the solubilisation of $\mathrm{Mg}(\mathrm{OH})_{2}$ when contacted with $\mathrm{CO}_{2}$. These figures also showed that the concentration of $\mathrm{Mg}^{2+}$ in solution increased to the maximum value in the first 20 minutes and stabilized for another 20 minutes and then fell to a final stable level. This implied that at a high concentration of $60 \mathrm{~g} / \mathrm{L}$, not all of the magnesium hydroxide will be carbonated to form $\mathrm{Mg}\left(\mathrm{HCO}_{3}\right)_{2}$

$\mathrm{P}_{\text {gas }}=\mathrm{kC}($ at constant $\mathrm{T})$

Where, $\quad \mathrm{P}=$ gas partial pressure $(\mathrm{Pa})$

$\mathrm{k}=$ Henry's law constant $\left(\mathrm{Pa} \mathrm{m}^{3} \mathrm{~mol}\right)$

$\mathrm{C}=$ concentration of the gas $(\mathrm{mol} / \mathrm{L})$
Alaee et al. [10] showed that the air/water Henry's Law constant $(\mathrm{K})$ is defined as the ratio of the concentration of a chemical in the gas phase to its concentration in the aqueous phase.

$$
K=\frac{P_{i}}{C_{w}}
$$

Where, $\mathrm{K}$ is in $\mathrm{Pa} \cdot \mathrm{m}^{3} \mathrm{~mol}$; $\mathrm{P}$, is partial pressure $(\mathrm{Pa})$ and $\mathrm{C}$, is aqueous concentration $(\mathrm{mol} / \mathrm{L})$.

The temperature effect on the Henry constant $\mathrm{K}$ can be expressed as:

$$
\text { Ln } \mathrm{K}=K=\frac{P_{i}}{C_{w}}
$$

Where $\mathrm{T}$ is temperature in $\mathrm{K}, \mathrm{A}$ and $\mathrm{B}$ are constants of the Van't Hoff equation.

Ten-Hulscher et al. [11] showed that $\mathrm{B}$ is the ratio of the enthalpy of volatilization to the gas constant, $\Delta \mathrm{H}_{\mathrm{o}} / \mathrm{R}$ in $\mathrm{K}^{-1}$, and $\mathrm{A}$ is the ratio of the entropy of volatilization to the gas constant $\Delta S_{0} / R$, resulting in a dimensionless value.

\section{Measured versus predicted solubility values}

Table 1 shows a comparison of the predicted and determined values for the effect of various parameters on the solubilisation of $\mathrm{Mg}(\mathrm{OH})_{2}$ and $\mathrm{BaSO}_{4}$ in a $\mathrm{CO}_{2}$-rich solution. The predictions were done using the Visual MINTEQ [8,9] model. The model was designed to simulate equilibrium and speciation of inorganic solutes in natural waters.

Temperature and sulphate: Figures 6 (experiment 1) and 7 (experiment 2) compare the solubility of $\mathrm{Mg}\left(\mathrm{HCO}_{3}\right)_{2}$ at 1 atm $\mathrm{CO}_{2}$ when no $\mathrm{BaSO}_{4}$ and $14 \mathrm{~g} / \mathrm{L} \mathrm{BaSO}_{4}$, respectively, were present over the temperature range $0-45^{\circ} \mathrm{C}$. Both sets of results showed that the final "solubility" of $\mathrm{Mg}(\mathrm{OH})_{2}$ increases with decreasing temperature. The measured "solubility" values for $\mathrm{Mg}(\mathrm{OH})_{2}$, when contacted with $\mathrm{CO}_{2}$ were lower than predicted by Visual Minteq. This can be ascribed to the high concentrations in solution which exceeded the model's operation range.

The results of experiment 2 in Table 1 show the predicted values for $\mathrm{Ba}^{2+}$ at $0^{\circ} \mathrm{C}$ in the treated water. The $\mathrm{Ba}^{2+}$ concentration increased from 6.4 to $24.3 \mathrm{mg} / \mathrm{L}$ for a temperature change of $45^{\circ} \mathrm{C}$. It is preferred to have $\mathrm{Ba}^{2+}$ concentrations of less than $2 \mathrm{mg} / \mathrm{L}$ in treated water as this is within the expected range in natural waters. This can be achieved by allowing a low residual sulphate concentration of at least $10 \mathrm{mg} / \mathrm{L}$ in the treated water. The residual sulphate ion will act as a common ion which decreases barium solubility. Figure 8 (Experiments 4 and 5) showed that, at $25^{\circ} \mathrm{C}$, a $\mathrm{Ba}^{2+}$ concentration of less than $2 \mathrm{mg} / \mathrm{L}$ at a

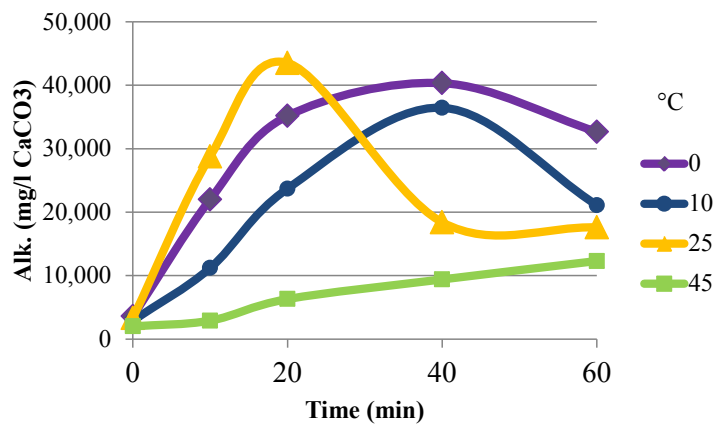

Figure 6: Effect of temperature on the rate of formation and solubility of $\mathrm{Mg}\left(\mathrm{HCO}_{3}\right)_{2}$ at low pressure (1 atm) under $\mathrm{BaSO}_{4}$-free conditions $(60 \mathrm{~g} / \mathrm{L}$ $\left.\mathrm{Mg}(\mathrm{OH})_{2}\right)$. 


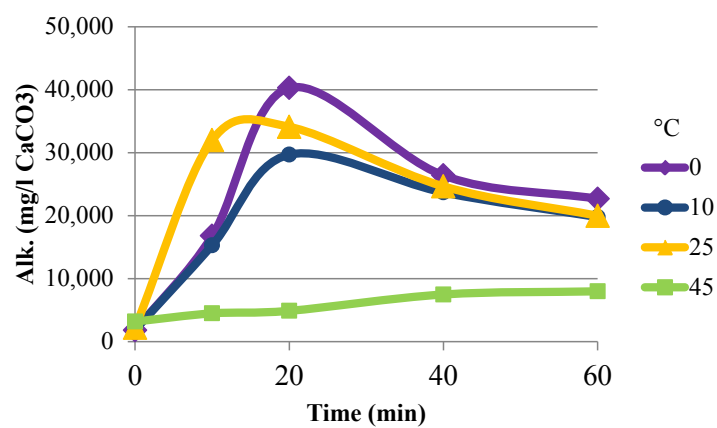

Figure 7: Effect of temperature on the rate of formation and solubility of $\mathrm{Mg}\left(\mathrm{HCO}_{3}\right)_{2}$ In the presence of $\mathrm{BaSO}_{4}\left(60 \mathrm{~g} / \mathrm{L} \mathrm{Mg}(\mathrm{OH})_{2}, 14 \mathrm{~g} / \mathrm{L} \mathrm{BaSO}\right)_{4}$.

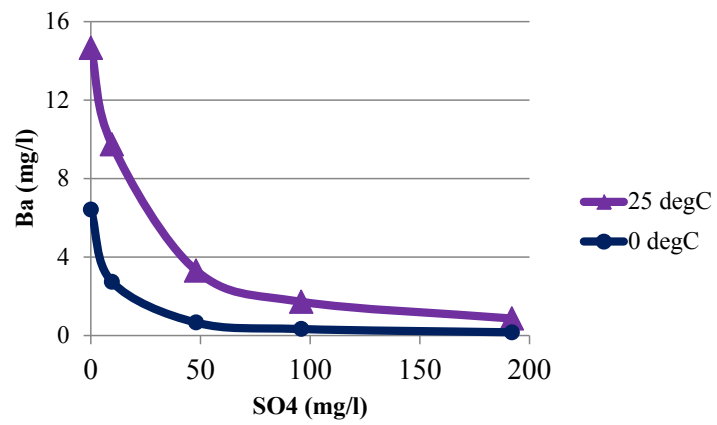

Figure 8:Effect of sulphate concentration in treated water on residual barium(II).

sulphate concentration of $100 \mathrm{mg} / \mathrm{L}$. At $0^{\circ} \mathrm{C}$ a sulphate concentration of $25 \mathrm{mg} / \mathrm{L}$ sulphate was sufficient to keep the $\mathrm{Ba}^{2+}$ concentration at less than $2 \mathrm{mg} / \mathrm{L}$.

Pressure: Rukuni at al. [12] showed that the solubility of $\mathrm{Ca}\left(\mathrm{HCO}_{3}\right)_{2}$ is influenced by pressure. It was also planned to investigate the effect of pressure on $\mathrm{Mg}\left(\mathrm{HCO}_{3}\right)_{2}$ solubility. Due to the high solubility of $\mathrm{Mg}\left(\mathrm{HCO}_{3}\right)_{2}$ at ambient pressure and temperature this was seen as less practical in the context of the process being developed. The high concentration also does not allow the use of the Visual Minteq $[8,9]$ model to predict the solubility at various pressures.

\section{Cost}

The process cost for this process is low because all the process raw materials $\left(\mathrm{CO}_{2}\right.$ and the $\mathrm{Mg}(\mathrm{OH})_{2}-\mathrm{BaSO}_{4}$ sludge $)$ are waste products of the TUT-MBO process (Figure 1). It is also foreseen that the cost can also be kept low in other applications by producing $\mathrm{CO}_{2}$ on-site by burning coal and scrubbing in water than the purchase of pure $\mathrm{CO}_{2}$.

\section{Conclusions}

It was found that:

- $\mathrm{Mg}(\mathrm{OH})_{2}$ can be separated from $\mathrm{BaSO}_{4}$ and $\mathrm{Mg}(\mathrm{OH})_{2}$ in a mixed sludge by carbonating it to $\mathrm{Mg}\left(\mathrm{HCO}_{3}\right)_{2}$ using $\mathrm{CO}_{2}$.

- The dissolution rate of $\mathrm{Mg}(\mathrm{OH})_{2}$ in the presence of $\mathrm{CO}_{2}$ is fast in the initial 20 minutes of the reaction.
- $\mathrm{Mg}(\mathrm{OH})_{2}$ had a high solubility of about $22700 \mathrm{mg} / \mathrm{l}$ when in contact with $\mathrm{CO}_{2}$ at $1 \mathrm{~atm}$, while $\mathrm{BaSO}_{4}$ is almost completely insoluble.

- The solubility of $\mathrm{Mg}(\mathrm{OH})_{2}$ increases with decreasing temperature and increasing pressure.

- The Visual Minteq model was a powerful tool to predict the "solubility" of $\mathrm{Mg}(\mathrm{OH})_{2}$ and $\mathrm{BaSO}_{4}$ when contacted with $\mathrm{CO}_{2}$.

Thus, the TUT-MBO process offers a sustainable method for neutralization, metal removal and desalination of AMD and recovery of saleable and reusable products from the mixed sludge produced. Because $\mathrm{Mg}\left(\mathrm{HCO}_{3}\right)_{2}$ has high solubility at low temperatures and high pressure, the practical optimal operation conditions for the dissolution reaction are temperatures close to $0^{\circ} \mathrm{C}$ and atmospheric pressure. This is because high pressures need sophisticated reactor designs and the systems are more complicated to run that those at atmospheric pressure conditions.

\section{Acknowledgment}

The financial support from THRIP and the laboratory facilities from Tshwane University of Technology are greatly acknowledged.

\section{References}

1. Department of Water Affairs (2010) Report to the inter-ministerial committee on acid mine drainage. Mine water management in the Witwatersrand gold fields with special emphasis on acid mine drainage.

2. Maila D, Maree JP, Zvinowanda CM, Kolesnikov AV, Louw WJ (2012) Treatment of Acid mine drainage using ammonium hydroxide. The 27th International Conference on Solid Waste Technology and Management, Philadelphia, USA. 11-14 March (2012).

3. V Bologo, JP Maree and WJ Louw (2012) Neutralization of acid mine drainage with magnesium bicarbonate, WISA Biennial Conference, Cape Town International Conference Centre, 18-22 April (2012).

4. Bologo V, Maree JP, Carlsson F (2012) Application of magnesium hydroxide and barium hydroxide for the removal of metals and sulphate from mine water. Water SA 38: 23-28.

5. Mucci A (1983) The solubility of calcite and aragonite in seawater at various salinities, temperatures and 1 atmosphere total pressure. Am J Sci 283: 780 799.

6. Millero F J (1995) Thermodynamics of the carbon dioxide system in the oceans. Geochim Cosmochim Acta 59: 661- 677.

7. Dickson AG (1984) pH scales and proton-transfer reactions in saline media such as seawater. Geochim Cosmochim Acta 48: 2299-2308.

8. Visual MINTEQ, http://www2.Iwr.kth.se/English/OurSoftware/vminteq/Visual\%20MINTEQ_tutorial.pdf. (2000) (Accessed: 24/11/2011).

9. Mintek, http://www2.Iwr.kth.se/English/OurSoftware/vminteq/ (Accessed 24/11/2011).

10. Alaee M, Whittal RM, Strachan WMJ (1996) The effect of water temperature and composition on Henry's law constant for various PAHs. Chemosphere 32: 1153-1164.

11. Ten-Hulscher, TEM, Van Der Velde LE, Bruggeman WA (1992) Temperature dependence of henry's law constants for selected chlorobenzenes, polychlorinated biphenyls, and polycyclic aromatic hydrocarbons. Environ Toxicol Chem 11: 1595-1603.

12. Rukuni TT, Maree JP, Zvinowanda CM (2012) Recovery of calcium carbonate from a barium sulphate-calcium carbonate mixed sludge. The 27 th International Conference on Solid Waste Technology and Management, Philadelphia, USA 11-14 March (2012). 